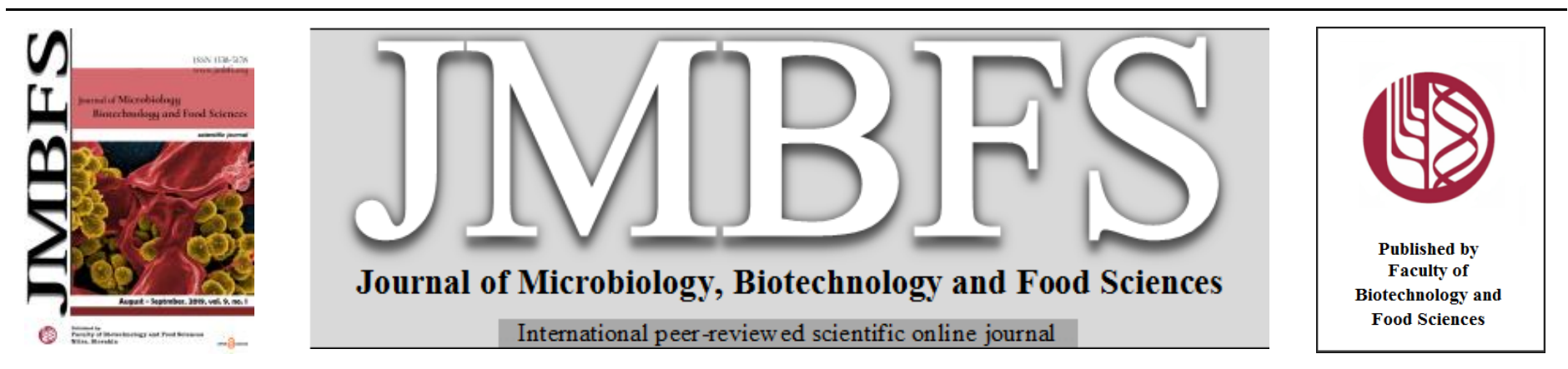

\title{
PHYSICOCHEMICAL AND FUNCTIONAL PROPERTIES OF STARCH FROM PHILIPPINE EDIBLE CANNA (Canna indica L.) RHIZOMES
}

\author{
Ara Fatima C. Algar* ${ }^{1}$, Aiza B.Umali ${ }^{l}$, Ryan Rodrigo P. Tayobong ${ }^{2}$ \\ Address(es): Ara Fatima C. Algar, MSc., \\ ${ }^{1}$ Institute of Food Science and Technology, College of Agriculture and Food Science, University of the Philippines Los Baños, 4031, Laguna, Philippines, \\ +63495362303 . \\ 2 Institute of Crop Science, College of Agriculture and Food Science, University of the Philippines Los Baños, 4031, Laguna, Philippines, +63495362468.
}

*Corresponding author: acalgar@up.edu.ph

doi: 10.15414/jmbfs.2019.9.1.34-37

ARTICLE INFO

Received 8. 3. 2018

Revised 2.3. 2019

Accepted 4. 3. 2019

Published 1. 8. 2019

Regular article

open $\partial_{\text {ACCESS }}$

\section{ABSTRACT}

Philippine edible canna (Canna indica L.), an underutilized crop in the Philippines, was utilized to produce starch to address the increasing demand and limited sources of starch. Starch was produced from the canna rhizomes using the wet method. The physicochemical and functional properties of the extracted Canna starch were then evaluated and compared with the commercially available and most often used cornstarch and potato starch. The non-starch components (moisture content, ash, crude fat, crude protein and reducing sugars) were determined and found to be within the range for good quality starches according to international standards. The canna starch granules were oblong shaped and were larger in size $(59.29 \mu \mathrm{m})$ compared to potato and corn starch granules. The swelling $\left(76.33^{\circ} \mathrm{C}\right)$ and bursting temperatures $\left(79.33^{\circ} \mathrm{C}\right)$, solubility in water $(9.81 \%)$, and water binding capacity $(6.63 \mathrm{~g} / \mathrm{g})$ were also evaluated. It has an amylose content of 35.99\% and found to form a hard gel with a least gelling concentration of $8.10 \%$, gel clarity of $13.03 \%$, and consistency of $0.47 \mathrm{~cm} / \mathrm{s}$. With these properties, canna starch can be used in confectioneries, noodle-making, and as thickeners in soups and sauces.

Keywords: Canna indica L., starch extraction, physicochemical properties, functional properties

\section{INTRODUCTION}

Starch is considered as one of the most important plant products for human consumption as it provides a large portion of the daily calorific intake (Burrell, 2003). It is considered as a versatile and cheap material and has many uses such as thickener, water binder, emulsion stabilizer, and gelling agent; thus, its form and functionality are always studied (Copeland, et al., 2009).

The major sources of starch for food use are cereals, but roots and tubers are also important. Among the main crops that are harvested for starch production are maize, rice, wheat, and potato which are also considered as staple food crops. Because of the many uses of starch, its demand also increases. In the Philippines, the commodity group which includes cereals, flour, starch, and pastry products is among the top ten of agricultural imports. Its total import value amounted to 428 million USD with a 9.8\% increase in the year 2017 (Philippine Statistics Authority, 2018). In 2015 alone, a total gross weight of $20 \mathrm{M} \mathrm{kg}$ of cornstarch and $95 \mathrm{M} \mathrm{kg}$ of cassava starch were imported by the Philippines mainly from Indonesia, Korea, Thailand, and Vietnam (Philippine Statistics Authority, 2015).

Thus, there is a need to have more studies on other possible sources of starch. Asian markets then recommend the use of root and tuber crops, the "inexpensive sources of energy and carbohydrate", as an effective competitor for cereal sources (Fuglie, 1999).

Edible canna (Canna indica $\mathrm{L}$.) is a starchy root crop that belongs to the Family Cannaceae (Hermann, 1996). In the Philippines, the crop is commonly used as an ornamental plant due to its bright red to orange flowers, but its rhizomes has very little account when it comes to food use. It is the rhizome which contains the starch with a yield that ranges from $12 \%$ to $16 \%$. In Vietnam, canna starch is widely used in making transparent starch noodles, a product that is originally made from mung bean starch (Hermann, 1996). According to Piyachomkwan $\boldsymbol{e}$ al. (2002), its starch can be a possible substitute to the starches that are now commercially available for food and industry uses. It is very adaptable that it is now widely distributed in many countries including Australia, Indonesia, Taiwan and Philippines.

With further studies, the future of this plant will be known in the food industry. Thus, the determination of the basic physicochemical and functional properties of canna starch will provide baseline information for its further utilization and product application in the Philippines.

\section{MATERIAL AND METHODS}

\section{Material}

Philippine edible canna rhizomes were collected from the Crop Production and Management Division of the Institute of Crop Science, College of Agriculture and Food Science, University of the Philippines Los Baños, Laguna.

\section{Starch extraction by wet-milling}

Starch extraction method was adapted from Peroni et al. (2007) with some modifications. The rhizomes were washed with water, peeled, cut into pieces, and soaked in $0.05 \%$ sodium metabisulfite solution for 15 mins. Then it is passed through a grinder with ample amount of water where the resulting product was passed through vibrating 80- and 100-mesh mechanical sieve (Ta Tung Automatic machinery Co. Ltd.). The collected slurry was then allowed to pass through 200-mesh sieve and the filtrate was left to stand overnight. The following day, the starch sediment was collected and washed several times with distilled water until clear. The collected starch was dried at $38^{\circ} \mathrm{C}$, ground, and allowed to pass a 200-mesh sieve.

\section{Determination of non-starch components}

Non-starch components of the extracted Canna starch was determined using Standards methods of AOAC (2005) to asses its purity. Moisture content was determined by oven-drying method (AOAC - 930.15), ash content by dry ashing (AOAC - 923.03), crude fat by Soxhlet method (AOAC - 945.16), crude proteins by Kjeldahl method (AOAC 920.87), and sugars by DNS method. 


\section{Determination of granule shape, size, and gelatinization temperature}

The canna starch granules were observed under the microscope with an ocular micrometer using high power objective. On the other hand, the gelatinization temperature was determined following modified method of Cai et al. (2014) using a hot-stage microscope from $25^{\circ} \mathrm{C}$ to $100^{\circ} \mathrm{C}$. The temperatures where granules started to swell and burst were recorded.

\section{Determination of amylose content}

The amylose content of the starch was determined using iodine and colorimetric method as described by Sadasivam and Manickam (1996). About 100mg of the sample was placed in test tubes, added with $1 \mathrm{~mL}$ of ethanol, $10 \mathrm{~mL}$ of $1 \mathrm{~N} \mathrm{NaOH}$ and left overnight. After that, the volume was diluted to $100 \mathrm{~mL}$. A $2.5 \mathrm{~mL}$ aliquot was added with $20 \mathrm{~mL}$ of distilled water, 3 drops of phenolphthalein indicator, $1 \mathrm{~mL}$ Iodine reagent, and the volume was made up to $50 \mathrm{~mL}$. The absorbance was read at $590 \mathrm{~nm}$. Standards of amylose solutions were also prepared and color was allowed to develop as in the case of the sample. A blank was prepared by diluting $1 \mathrm{~mL}$ of iodine reagent to $50 \mathrm{~mL}$ using distilled water. The amount of amylose present in the sample was calculated using the standard graph. Calculation of $\%$ amylose was done as follows:

$$
\% \text { Amylose }=\frac{\mathrm{x}}{2.5} \times 100 \mathrm{mg} \text { amylose }
$$

\section{Determination of water solubility and binding properties}

Solubility of the starch sample was determined using the method of Yuan et al. (2007). Approximately $25 \mathrm{~mL}$ of $2 \%$ (w/w) starch suspension was prepared and incubated in a water bath with a constant temperature $\left(70^{\circ} \mathrm{C}\right)$ for 30 mins. After 30 mins, the sample was cooled to room temperature then centrifuged (BHG Heka no. 22067v01) at $300 \mathrm{r} / \mathrm{min}$ for $20 \mathrm{mins}$. Solubility was determined by measuring the solid content of the supernatant in the tube. Calculation of $\%$ solubility was done using the formula:

$$
\% \text { Solubility }=\frac{\text { Solid content of supernatant }}{\text { Dry weight of starch sample }} \times 100
$$

Water binding capacity was measured using the method of Bryant and Hamaker (1977). Approximately $0.5 \mathrm{~g}$ of the starch was placed in a pre-weighed test tube and added with water. The tube was heated to $70^{\circ} \mathrm{C}$ in a water bath, centrifuged for $10 \mathrm{mins}$ at $2500 \mathrm{xg}$, and the supernatant was decanted. Water binding capacity was expressed as the gain in weight of the tubes.

\section{Determination of gel concentration, strength, clarity and consistency}

Least gelling concentration was determined by using the method of Coffman and Garcia (1977) as cited by Aremo et al. (2008). Starch suspensions of 1 to $10 \%$ (with $1 \%$ interval) were prepared in distilled water and $10 \mathrm{~mL}$ of each dispersion was transferred into test tubes. The tubes were heated in boiling water bath until gelatinized and was followed by rapid cooling in cold water bath. The tubes were further cooled at $4^{\circ} \mathrm{C}$ overnight. The least gelling concentration was determined as the concentration when the sample from the inverted tube did not slip or fall. The gel strength was determined using the method of Cagampang et al. (1973). About $100 \mathrm{mg}$ of the starch was placed in test tubes, added with $0.2 \mathrm{~mL} 95 \%$ ethanol containing $0.025 \%$ thymol blue, mixed, and was added with $2.0 \mathrm{~mL} 0.2 \mathrm{~N}$ $\mathrm{KOH}$ immediately. The tubes were covered and heated in boiling water bath for 8 mins. The tubes were cooled at room temperature for 5 mins and in ice cold water for 15 mins. The tubes were then placed horizontally over a paper graduated in millimeters and the strength of the gel was measured from the bottom after 30 mins. A gel is considered soft with a measurement of $61-100 \mathrm{~mm}$, medium for 41 $60 \mathrm{~mm}$, medium-hard for $36-40 \mathrm{~mm}$, and hard for $26-35 \mathrm{~mm}$.

Paste clarity was determined by analyzing the light transmittance (\% $\mathrm{T})$ of the starch paste. Starch $(50 \mathrm{mg})$ was suspended in $5 \mathrm{~mL}$ of water in a screw-cap tubes. It was placed in the boiling water bath for 30 mins with shaking at every 5 minute interval. After cooling to room temperature for $5 \mathrm{mins}$, \% light transmittance was determined at $650 \mathrm{~nm}$ against a water blank (Craig et al., 1989).

Consistency of the starch was determined using Bostwick consistometer. A 3\% w/w starch solution was prepared, heated until gelatinized, and cooled to room temperature. Using a Bostwick consistometer, the gelatinized starch was allowed to flow for $30 \mathrm{secs}$ and the distance travelled by the sample was recorded. The consistency was determined using the formula:

$$
\text { Consistency, } \frac{\mathrm{cm}}{\mathrm{s}}=\frac{\text { distance travelled, } \mathrm{cm}}{\text { time, } \mathrm{sec}}
$$

\section{RESULTS AND DISCUSSION}

\section{Non-starch components}

Quantitative analysis of the non-starch components of the canna starch was done to assess its purity and quality. As shown in Table 1, the values of moisture content $(10.08 \%)$, ash content $(0.24 \%)$, crude fat $(0.24 \%)$, crude protein $(2.21 \%)$, and reducing sugars $(84.19 \mathrm{mg} / 100 \mathrm{~g})$ fall within the parameters for a good quality starch according to the Codex standards.. In addition, the low moisture content is ideal for its storage stability and long shelf-life while the low protein content is desirable as it influences the water penetration during cooking and results to rapid rate of starch gelatinization (Bemiller and Whistle, 2009).

Table 1 Non-starch components of canna starch.

\begin{tabular}{lcc}
\multicolumn{1}{c}{ Components } & Canna Starch & Standards of Starch* \\
\hline Moisture Content $(\%)$ & $10.08 \pm 0.06$ & $10.00-13.50 \%$ \\
Crude Ash $(\%)$ & $0.24 \pm 0.04$ & $\leq 1.00 \%$ \\
Crude Fat $(\%)$ & $0.24 \pm 0.01$ & $\leq 1.50 \%$ \\
Crude Protein $(\%)$ & $2.21 \pm 1.03$ & $<3.00 \%$ \\
Reducing Sugar $(\mathrm{mg} / 100 \mathrm{~g})$ & $84.19 \pm 2.05$ & Very low
\end{tabular}

* Codex Standards

\section{Starch granule shape and size}

Table 2 and figure 1 shows the comparison of the granules of the three starches. Canna and potato starch granules were both oblong in shape while the corn starch granules which were spherical (irregular). According to Wetzel and Charalambous (1998), starch granule shape is affected by the growing climatic condition. Humid conditions result in regularly-shaped granules with concentric layers around the hilum. Among the three starches, canna starch granules were found to have the largest size $(59.29 \mu \mathrm{m})$ followed by potato $(52.03 \mu \mathrm{m})$ and corn $(15.73 \mu \mathrm{m})$. The large size of the canna and potato starches could be attributed to the age of the storage tissues. According to BeMiller and Whistler (2009), there is a direct relationship between the average granule size and age of storage tissues such as those observed in common starch sources such as rice, potato tubers, and pea cotyledons.

Table 2 Physical properties of canna, corn, and potato starches.

\begin{tabular}{lccc}
\hline \multicolumn{1}{c}{ Parameters } & Canna & Corn & Potato \\
& starch & starch & starch \\
\hline Granule Shape & Oblong & Spherical & Oblong \\
Granule size range $(\mu \mathrm{m})$ & $24.20-94.38$ & $7.26-24.2$ & $21.78-82.28$ \\
Average Granule Size $(\mu \mathrm{m})$ & 59.29 & 15.73 & 52.03 \\
\hline
\end{tabular}

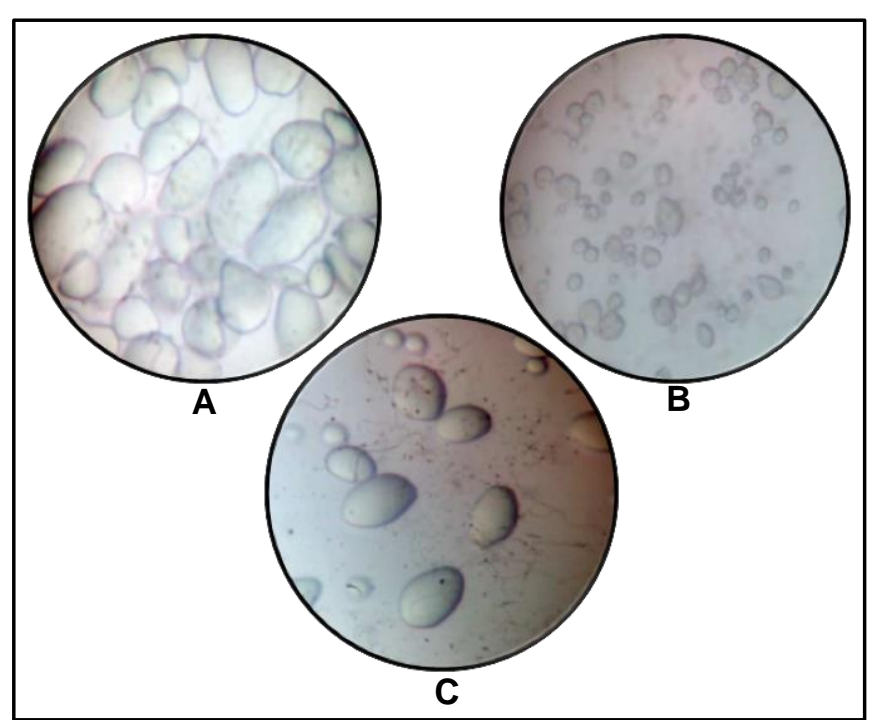

Figure 1 Starch granules observed under HPO (400x). A. Canna starch granules, B. Cornstarch granules, C. Potato starch granules. Amylose content

Table 3 shows that there is no significant difference among the obtained amylose content for the three starches. Amylose contents of canna, corn, and potato starches were $35.99 \%, 30.44 \%$, and $32.89 \%$, respectively. Common starches are mostly compose of 20-30\% amylose and 70-80\% amylopectn (Ayadi et al., 2016). Of the two components of starch, amylose has the most useful functions as 
a hydrocolloid as it is the major factor for gel and film formation. In addition, gelatinization, retrogradation properties, swelling properties, and the enzymatic susceptibility of starch are all affected by the amylose content (Peroni $\boldsymbol{e t}$ al. 2006). In a study conducted by BeMiller and Whistler (2009), it was found that an optimum level of amylose at around 32-44\% results to better cooking of pasta. With this range of amylose content, extensible dough with increased pasta firmness and decreased water absorption was obtained. The amylose content of canna starch is within this range, thus, suggesting its possible use in making pasta or noodles.

Table 3 Amylose content of canna, corn, and potato starches.

\begin{tabular}{cc} 
Table 3 Amylose content of canna, corn, and potato starches. \\
\hline Sample & Amylose content, \% \\
\hline Canna starch & $35.99 \pm 1.35^{\mathrm{a}}$ \\
Cornstarch & $30.44 \pm 0.87^{\mathrm{a}}$ \\
Potato starch & $33.89 \pm 1.08^{\mathrm{a}}$ \\
\hline
\end{tabular}

Means followed by the same letter in a column denote values that are not significantly different at $\alpha=0.05$.

\section{Functional properties of Starch}

The functional properties of canna starch were compared to cornstarch and potato starch as shown in Table 4. The functional properties determined included the gelatinization temperatures, solubility in water, water binding capacity, least gelling concentration, paste clarity, and consistency.

The gelatinization temperatures of the three starches were expressed as swelling and bursting temperatures. At the swelling temperature, water had already penetrated the granules resulting to the increase in size compared to the original (Brown, 2014). The obtained swelling temperature for canna starch $\left(76.33^{\circ} \mathrm{C}\right)$ was significantly higher compared to that of corn $\left(71.33^{\circ} \mathrm{C}\right)$ and potato $\left(67.00^{\circ} \mathrm{C}\right)$ The granule size determines the swelling functionality wherein granules which are generally elongated, which is the Canna starch among the three samples, have less swelling power (Ao and Jane, 2007) thus higher

Table 4 Functional properties of canna, corn, and potato starches.

\begin{tabular}{lccc}
\hline \multicolumn{1}{c}{ Parameters } & Canna starch & Cornstarch & Potato starch \\
\hline Gelatinization Temperature $\left({ }^{\circ} \mathrm{C}\right)$ & & & \\
$\quad$ Swell & $76.33 \pm 3.06^{\mathrm{a}}$ & $71.33 \pm 2.08^{\mathrm{b}}$ & $67.00 \pm 1.73^{\mathrm{b}}$ \\
Burst & $79.33 \pm 3.06^{\mathrm{a}}$ & $75.33 \pm 1.15^{\mathrm{a}}$ & $70.33 \pm 1.53^{\mathrm{b}}$ \\
Solubility in Water (\%) & $9.81 \pm 0.10^{\mathrm{b}}$ & $11.30 \pm 0.13^{\mathrm{a}}$ & $9.00 \pm 0.17^{\mathrm{c}}$ \\
Water Binding Capacity (g/g) & $6.63 \pm 1.42^{\mathrm{b}}$ & $9.59 \pm 1.26^{\mathrm{b}}$ & $28.85 \pm 1.81^{\mathrm{a}}$ \\
Least Gelling Concentration (\%) & 8.10 & 5.03 & 8.16 \\
Gel Strength & Hard & Soft & Medium $^{\mathrm{a}}$ \\
Paste Clarity (\%T) & $13.03 \pm 0.72^{\mathrm{b}}$ & $7.87 \pm 0.40^{\mathrm{c}}$ & $26.67 \pm 1.63^{\mathrm{a}}$ \\
Consistency (cm/s) & $0.47 \pm 0.02^{\mathrm{b}}$ & $0.67 \pm 0.09^{\mathrm{a}}$ & $0.34 \pm 0.04^{\mathrm{c}}$ \\
\hline
\end{tabular}

Means followed by the same letter in a row denote values that are not significantly different at $\alpha=0.05$.

temperature needed. After reaching its peak thickness upon swelling, the amylose migrates out of the granules and the water becomes less available, thus, resulting to an increase in thickness (Brown, 2014). This is the time when the bursting temperatures of the starches were taken. For the bursting temperature, the obtained value for canna starch $\left(79.33{ }^{\circ} \mathrm{C}\right)$ was also significantly higher compared to that of corn $\left(75.33{ }^{\circ} \mathrm{C}\right)$ and potato $\left(70.33^{\circ} \mathrm{C}\right)$ starches. Due to the high gelatinization temperature of canna starch, this can be applied to food products which require high temperature processing or extended cooking time such as extruded snacks.

The solubility in water of the three starches was found to be significantly different from each other. Corn starch has the highest solubility $(11.30 \%)$ followed by canna starch $(9.81 \%)$ and potato starch $(9.00 \%)$. Starch solubility can be attributed to the easy breakdown of the starch linear fraction, which is the amylose portion which will then be released or leached out (Soni et al., 1993). This is important for making sauces wherein the starch needs to be dissolved in the liquid component.

In addition, the water binding capacity of potato starch $(28.85 \mathrm{~g} / \mathrm{g})$ is significantly higher compared to that of canna $(6.63 \mathrm{~g} / \mathrm{g})$ and corn $(9.59 \mathrm{~g} / \mathrm{g})$. According to $\mathrm{Ni}$

Amoo et al. (2014), high water binding capacity is desirable because it protects the products from effects of syneresis that occurs after retorting or freezing. Since canna starch has a low water binding capacity, it is not recommended to use this in products manufactured in bulk as it is prone to syneresis.

The least gelling concentration of canna was found to be $8.10 \%$ which is comparable to potato starch $(8.16 \%)$. This is the minimum amount of starch needed to form a gel. In addition, the gels formed from canna starch can be considered as a hard gel according to the classification of Cagampang et al. (1973). This property gives canna starch the high possibility to be used in confectionery products (Nussinovitch and Hirashima, 2013) wherein the bulk of the starch used is for molding and dusting. The gel strength is primarily affected by the amount of amylose (Sharma, 2007). High amount of amylose, as showed in Table 3, results to increased gel strength, thus, forming harder gel (Chung and Liu, 2009).

Significant differences had been observed for the paste clarity of the three starches, potato had the highest clarity $(26.67 \%)$ followed by canna $(13.03 \%)$, and corn starch $(7.87 \%)$. The differences in the paste clarity of the three starches can be attributed to how the system of starch and water transmit, reflect, and refract light (Craig et al., 1989). The high clarity of potato starch is due to the covalently bound phosphate groups which contribute to molecular dispersion in the solution resulting to clearer paste.

The obtained consistency for the three starches differs significantly from each other. Corn has the highest value for consistency $(0.67 \mathrm{~cm} / \mathrm{s})$ which means that it flows faster after gelatinization. It was then followed by canna $(0.47 \mathrm{~cm} / \mathrm{s})$ and potato $(0.34 \mathrm{~cm} / \mathrm{s})$. Since canna starch has low consistency it can be used as a thickening agent.

\section{CONCLUSION}

Starch was extracted from the rhizomes of the underutilized and indigenous Philippine edible Canna and was assessed to be within the limit set for good quality starches. After comparing it to the commercially available cornstarch and potato starch, it was found that the shape and size of the canna starch granules was comparable to potato starch granules. The high amylose content can highly contribute to good textural properties. It has the lowest water binding capacity but the highest gelatinization temperature and can form hard-type gels. Finally, canna starch have the potential to be used in the food industry such as in confectioneries, noodle-making, and thickeners for several food products.

Acknowledgments: The authors would like to acknowledge the Department of Agriculture - Bureau of Agricultural Research for the research funding and to the Institute of Crop Science of UPLB as the research collaborator.

\section{REFERENCES}

Ao, Z. and Jane, J. (2007). Characterization and modelling of the A- and Bgranule starches of wheat, triticale, and barley. Carbohydrate Polymers, 67:4655. https://doi.org/10.1016/j.carbpol.2006.04.013

AOAC. (2005). Official methods of Analysis of the Association of Officiail Analytical Chemists, 20th edition, Washington, D.C.

Aremu, M.O, Olaofe, O., Akintayo, E.T., and Adeyeye E.I. (2008). Foaming, water absorption, emulsification and gelation proerties of Kersting's groundnut (Kerstingiellageocarpa) and Bambara groundnut (Vigna subterranean) flours as influence by neutral salts and their concentrations. Pakistan Journal of Nutrition 7(1): 194- 201. http://dx.doi.org/10.3923/pin.2008.194.201

Ayadi, F.Y., Rosentrater, K.A., Muthukumarappan, K., and Kannadhason, S. (2016). Effects of amylose-to-amylopectin ratios on binding capacity of DDGS/Soy-based aquafeed blends. Journal of Food Research 5(5): 43-56 http://dx.doi.org/10.5539/jfr.v5n5p43

Bemiller, J.N. and Whistler, R.L. (2009). Starch: Chemistry and technology. 3rd Edition. United States of America: Academic Press - Elsevier, Inc.

Brown, A.C. (2014). Understanding food: Principles and preparation. $5^{\text {th }}$ edition. United States of America: Cengage Learning. p. 392.

Bryant, C.M. and Hamaker, B.R. (1997). Effect of lime on gelatinization of flour and starch. Cereal Chemistry 74(2): 171- 175.

http://dx.doi.org/10.1094/CCHEM.1997.74.2.171

Burrell, M.M. (2003). Starch: The need for improved quality or quantity - an overview. Journal of Experimental Botany 54(382):451-456. https://doi.org/10.1093/jxb/erg049

Cagampang, G.B., Perez, C.M., and Juliano, B.O. (1973). A gel consistency test for eating quality of rice. Journal of the Science of Food and Agriculture 24: 1589- 1594. http://dx.doi.org/10.1002/jsfa.2740241214 
Cai, C., Cai, J., Zhao, L. and Wei, C. (2014). In situ gelatinization of starch using hot stage microscopy. Food Science and Biotechnology 23(1): 15-22. https://doi.org/10.1007/s10068-014-0003-x

Chung, H.J. and Liu, Q. (2009). Impact of molecular structure of amylopectin and amylose on amylose chain association during cooling. Carbohydrate Polymers 77:807-815. https://doi.org/10.1016/j.carbpol.2009.03.004

Copeland, L., Blazek, J., Salman, H., and Tang, M.C. (2009). Form and functionality of starch. Food Hydrocolloids 23: 1527-1534. https://dx.doi.org/10.1016/j.foodhyd.2008.09.016

Craig, S.A., Maningat, C.C., Seib, P.A., and Hoseney, R.C. (1989). Starch paste clarity. Cereal Chemistry 66(3): 173-182.

www.aaccnet.org/publications/cc/backissues/1989/Documents/66_173.pdf

Fuglie, K. (1999). Raw Materials for starch in Asia: Some economic considerations. UPWARD Fieldnotes (Philippines) 7(2): 5-7.

Hermann, M. (1996). Starch noodles from edible canna. In: J. Janick ed. Progress in new crops. Arlington, Virginia: ASHS Press. p. 507-508.

Mengistu, S.L. and Shimelis A.E. (2012). Evaluation of the physicochemical properties of Ethiopian maize variety (BH- 600) for dextrose production. African Journal of Food, Agriculture, Nutrition and Development 12(5): 6503-6516 http://www.bioline.org.br/pdf?nd12065

Nii Amoo, A.R., Dufie, W.F., and Ibok, O. (2014). Physicochemical properties of starch extracted from four yam varieties. Journal of Food and Nutrition Sciences 2(6): 262- 269. http://dx.doi: 10.11648/j.jfns.20140206.14

Nussinovitch, A. and Hirashima, M. (2013). Cooking innovations: Using hydrocolloids for thickening, gelling, and emulsification. Florida, USA: CRC Press. p. 233.

Peroni, F.G., Rocha, T.S., and Franco, C.L. (2006). Some structural and physicochemical characteristics of tuber and root starches. Food Science and Technology International 12(6): 505-513. https://doi/abs/ 10.1177/1082013206073045

Philippine Statistics Authority (2015). Foreign Trade Statistics of the Philippines 2015 Volume I-Imports. www.psa.gov.ph

Philippine Statistics Authority (2018). Highlights of the Foreign Trade Statistics for Agricultural Commodities: Philippines, 2017. www.psa.gov.ph

Piyachomkwan, K., Chotineeranat, S., Kijkhunasatian, C., Tonwitowat, R. Prammanee, S., Oates, C.G., and Sriroth, K. (2002). Edible canna (Cannaedulis) as complementary starch source to cassava for the starch industry. Industrial Crop and Products 16: 11-21. https://doi.org/10.1016/S0926-6690(02)00003-1 Sadasivam, S. and Manickam, A. (1996). Biochemical Methods. India: New Age International.

Sharma, V. (2007). Factors affecting starch conversion to ethanol in dry grind corn process. Proquest. p.6.

Soni, R.L., Sharma, S.S., Dun, D., Giharia, M.M., and Ahmedabad, J. (1993). Physico chemical properties of Quercus leucotrocophora (oak). Starch/Starke 45(4): 127-130. https://doi: 10.11648/j.jfns.20140206.14

Wetzel, D.L.B and Charalombous, G. (1998). Instrumental methods in food and beverage analysis. The Netherlands: Elsevier Science B.V. p.53.

Yuan, Y., Zhang, L., Dai, Y. and Jiugo, Y. (2007). Physicochemical properties of starch obtained from Dioscoreanipponica Makino comparison with other tuber starches. Journal of Food Engineering 82: 436-442. https://doi.org/10.1016/j.jfoodeng.2007.02.055 